\title{
Investigation of DNA binding and molecular docking propensity of phthalimide derivatives: in vitro antibacterial and antioxidant assay
}

\author{
Rizwan Arif ${ }^{1}$, Pattan Sirajuddin Nayab ${ }^{1}$, Akrema ${ }^{1}$, Mohammad Abid², Umesh Yadava ${ }^{3}$ and Rahisuddin ${ }^{1 *}$ (D)
}

\begin{abstract}
A series of $\mathrm{N}$-substituted tetrabromphthalimide derivatives was synthesized by condensation reaction using tetrabromophthalic anhydride with 3,5-diamino-1,2,4-triazole/ 2,6-diaminopyridine/ 2,6-diamino-4-hydroxy pyrimidine/ o-tolidine. All the synthesized phthalimide derivatives were characterized by elemental analysis, infrared, and NMR spectroscopy. In vitro antibacterial evaluation was carried out for the synthesized compounds. Results revealed that compound 1 showed potential activity against Escherichia coli $(100 \mu \mathrm{g} / \mathrm{mL})$ and Streptococcus mutans $(150 \mu \mathrm{g} / \mathrm{mL})$. On the basis of antibacterial activity, compound 1 was selected for DNA binding interaction, though DNA target most of the antibacterial drugs. The DNA binding modes of the compound 1 with Ct-DNA (calf thymus) were studied by absorption measurements, hydrodynamic measurements and cyclic voltammetry methods. Molecular docking also confirms that compound 1 recognizes both the strands of the DNA dodecamer d(CGCGAATTC GCG) 2 within minor groove and showing the best binding capability with the duplex. Compound 1 also showed better antioxidant activity by 2,2-diphenyl-1-picryl-hydrazyl (DPPH) free radical and hydrogen peroxide.
\end{abstract}

Keywords: Phthalimide, Antibacterial, Antioxidant, DNA, DPPH

\section{Introduction}

Heterocyclic phthalimides are well explored derivatives among important class of pharmacophores for the preparation of variety of drugs because of its similar structural properties (hydrophobic aryl ring and an electrondonating group), they possess variety of important biological activities. Due to its wide range of applications in medicinal chemistry and pharmaceutics (Bhat and Al-Omar 2011; Mohamed et al. 2015) viz. antibacterial (Lohan et al. 2014; Silva et al. 2014; Zhang et al. 2015), antifungal, anti-inflammatory (Buddana et al. 2015; Al-Qaisi et al. 2014), antivirus (Shi et al. 2011), antagonistic (Lin et al. 2009), and anti-androgens (Roy et al. 2007), it is an important and tremendous subject for today's research. Apart from their pharmaceutical applications, phthalimide also serves as herbicides (Balachandran et al. 2012), used in production of pesticides (Wang et al.

\footnotetext{
* Correspondence: Rahisuddin@jmi.ac.in

'Department of Chemistry, Jamia Millia Islamia, New Delhi 110025, India Full list of author information is available at the end of the article
}

2013) and dyes (Choi et al. 2010). They were also found with industrial applications as bleaching agent, heat-resistant polymer, and flame retardants (Krishnakumar et al. 2005). For the amine protection in organic synthesis, phthalimide moiety is an important constituent.

In the process of production, the knowledge of thermodynamic parameters or solvent crystallization is significant and process for purifying the phthalimide derivatives by virtue of crystallization method induces by the awareness of their solubility in appropriate solvent system. $\mathrm{Li}$ and his co-workers determine the solubility of various phthalimide derivatives experimentally by using the isothermal dissolution equilibrium method in mixed solvent systems ( $\mathrm{Li}$ et al. 2017). Phthalimide derivatives exhibited various biological activities and proved as a noteworthy pharmacophore and can interact with the peripheral anionic site of the enzyme. A series of phthalimide derivatives was synthesized as multi-function inhibitors for the treatment of Alzheimer's disease (AD) 
and found to be a balanced multi-target active molecule which exhibited potent and balanced inhibitory activities against cholinesterase inhibitors (Sang et al. 2017). Due to industrial development and high requirement, phthalimide was prepared on a large scale by various methods in high yield. Due to very low solubility in water, separation of phthalimide is not easy. Hence to rectify these problems, many methods have been developed by the researchers for the separation and purification of phthalimides in high yield (Kushwaha and Kaushik 2016). Heterocyclic phthalimide derivatives are very much useful for the construction of macromolecules, in supramolecular chemistry, useful in catalytic reaction and photochemistry (Yoon et al. 1997; Cho et al. 2010). A series of polyester derived from phthalimide, which are thermally stable and highly soluble in polar solvents, has been also reported (Behniafar et al. 2015).

DNA plays major role in many physiological and biological processes. Various targeting drugs for DNA which was approved as significant antimicrobial agents currently available in the market but due to their side effects and highly clinical costs, many researchers are working on developing new antimicrobial drugs. The biological activity of the antibacterial drugs containing heterocyclic ring is due to inhibition of DNA replication (Nayab et al. 2015a, b, 2016). In view of these prospective, the study of DNA interaction with phthalimides has been considered a subject of great importance for the investigation of potential antimicrobial and anticancer drugs and molecular docking technique can be used for knowing the aspect of intermolecular interactions of proteins and ligands.

Considering these facts, in the current research work, we have synthesized tetrabromo phthalimide derivatives by the condensation reaction of tetrabromo phthalic anhydride and 3,5-diamino-1,2,4-triazole/ 2,6-diaminopyridine/ 2,6-diamino-4-hydroxy pyrimidine/ $o$-tolidine in order to prepare potent antibacterial and DNA binding agents.

\section{Experimental}

\section{Materials and methods}

1,2,4-Triazole-3,5-diamine and tetrabromophthalic anhydride purchased from Sigma Aldrich Chemicals Pvt. Ltd. and 2,6-diaminopyridine, o-tolidine, 2,6-diamino-4-hydroxypyrimidine, and 2,2-diphenyl-1-picryl-hydrazyl (DPPH) from Merck, India. All the reagents were used as received without further purification. For thin-layer chromatography, precoated aluminum sheets (silica gel $60 \mathrm{~F}_{254}$, Merck, Germany) were used to monitor the reaction by using methanol:dichloromethane (1:4) as a solvent system and for the spots visualization UV light cabinet was used.

To perform elemental analysis, Vario Micro Elementar Analyzer was used. Electronic spectra were recorded on Perkin Elmer Lamda 40 UV-visible spectrophotometer. IR spectra were recorded on Agilent Cary 630 FTIR spectrometer as neat sample. ${ }^{1} \mathrm{H}$ NMR spectra were recorded on Bruker DPX-300 NMR spectrometer operating at $400 \mathrm{MHz}$ using DMSO- $\mathrm{d}_{6}$ as solvent with TMS as internal standard. Chemical shift values are given in $\mathrm{ppm}$. Cyclic voltammetric measurements were performed by using DY2312 potentiostat. The antibacterial experiment was performed against Streptococcus mutans (MTCC 3224), and Escherichia coli (ATCC 25922) bacterial strains. To perform molecular docking study Gaussian 03 software was used. The antioxidant potential of the phthalimide derivatives was also estimated using DPPH free radical and hydrogen peroxide assay.

\section{Synthesis of phthalimide derivatives}

Similar procedure was employed according to our earlier reported method (Arif et al. 2016). The color solids that obtained were filtered, washed with distilled water, and finally dried under vacuum on fused calcium chloride and recrystallized in chloroform.

4,5,6,7-tetrabromo-2-[3-(4,5,6,7-tetrabromo-1,3-dioxo-2,3-dihydro-1H-isoindol-2-yl)-1H-1,2,4-triazol-5-yll-2,3-dihydro-1H-isoindole-1,3-dione (1):

White solid; $\mathrm{mp}>300^{\circ} \mathrm{C} ; \mathrm{C}_{18} \mathrm{HN}_{5} \mathrm{O}_{4} \mathrm{Br}_{8}$ : yield $60 \%$; IR $\left(\mathrm{cm}^{-1}\right): v_{\mathrm{C}=\mathrm{O}(\text { asym) }} 1786, v_{\mathrm{C}=\mathrm{O} \text { (sym) }} 1736, v_{\mathrm{NH}} 3453 .{ }^{1} \mathrm{H}$ NMR (300 MHz, DMSO-d 6 ), $\delta_{\mathrm{H}} 9.46(\mathrm{~s}, 1 \mathrm{H}, \mathrm{NH}) .{ }^{13} \mathrm{C}$ NMR $\left(100 \mathrm{MHz}\right.$, DMSO-d $\left.\mathrm{d}_{6}\right) \delta$ in ppm 166.63, 145.02, $138.41,133.29,131.51,129.19,128.38,126.22,118.93$, 116.30. Anal. Calcd. for $\mathrm{C}_{18} \mathrm{HN}_{5} \mathrm{O}_{4} \mathrm{Br}_{8}: \mathrm{C}, 21.82 ; \mathrm{H}, 0.11$; $\mathrm{N}, 7.05$; found: $\mathrm{C}, 21.87 ; \mathrm{H}, 0.11 ; \mathrm{N}, 7.05$.

4,5,6,7-tetrabromo-2-[6-(4,5,6,7-tetrabromo-1,3-diox$o$-2,3-dihydro-1H-isoindol-2-yl)

pyridin-2-yll-2,3-dihydro-1H-isoindole-1,3-dione (2):

Brown solid; $\mathrm{mp}>300^{\circ} \mathrm{C}$; yield: $62 \%$; IR $\left(\mathrm{cm}^{-1}\right)$ : $v_{\mathrm{C}=\mathrm{O}(\text { asym })} 1780, v_{\mathrm{C}=\mathrm{O}(\mathrm{sym})} 1730 .{ }^{1} \mathrm{H}$ NMR $(300 \mathrm{MHz}$, DMSO- $\left.\mathrm{d}_{6}\right): \delta_{\mathrm{H}} 7.46(\mathrm{~d}, 2 \mathrm{H}, \mathrm{Ar}-\mathrm{H}) ; \delta_{\mathrm{H}} 9.84(\mathrm{~s}, 1 \mathrm{H}$, Ar-H). ${ }^{13} \mathrm{C}$ NMR (100 MHz, DMSO-d 6 ) $\delta$ in ppm $169.33,132.59,128.29,129.23,128.67,124.88,122.50$, 119.29, 112.79. MS (m/z): $1000.35(\mathrm{M}+1)$. Anal. Calcd. for $\mathrm{C}_{21} \mathrm{H}_{3} \mathrm{~N}_{3} \mathrm{O}_{4} \mathrm{Br}_{8}$ : C, 25.20; $\mathrm{H}, 0.30 ; \mathrm{N}, 11.03$; found: C, 25.24; $\mathrm{H}, 0.34 ; \mathrm{N}, 11.22$.

4,5,6,7-tetrabromo-2-[4-hydroxy-6-(4,5,6,7-tetrabromo-1,3-dioxo-2,3-dihydro-1H-isoindol-2-yl)pyrimidin-2-yl]-2,3-dihydro-1H-isoindole-1,3-dione (3):

Off-white solid; $\mathrm{mp}>255^{\circ} \mathrm{C}$; yield: $69 \%$; IR $\left(\mathrm{cm}^{-1}\right)$ : $v_{\mathrm{C}=\mathrm{O}(\text { asym })} 1783, v_{\mathrm{C}=\mathrm{O}(\text { sym })} 1720, v_{\mathrm{OH}} 3190 .{ }^{1} \mathrm{H}$ NMR $\left(300 \mathrm{MHz}, \mathrm{DMSO}-\mathrm{d}_{6}\right): \delta_{\mathrm{H}} 9.54(\mathrm{~s}, 1 \mathrm{H},-\mathrm{OH}) ; \delta_{\mathrm{H}} 5.02(\mathrm{~s}$, $1 \mathrm{H}$, Ar-H). ${ }^{13} \mathrm{C}$ NMR $(100 \mathrm{MHz}$, DMSO-d 6 ) $\delta$ in ppm $169.08,162.06,160.07,131.80,131.53,131.11,127.87$, 127.65, 126.42. MS (m/z): $1017.75(\mathrm{M}+1)$. Anal. Calcd. for $\mathrm{C}_{20} \mathrm{H}_{2} \mathrm{~N}_{4} \mathrm{O}_{5} \mathrm{Br}_{8}$ : C, 23.60; $\mathrm{H}, 0.19 ; \mathrm{N}, 5.50$; found: $\mathrm{C}$, 23.25; H, 0.34; N, 5.87 . 
4,5,6,7-tetrabromo-2-\{2-methyl-4-[3-methyl-4-(4,5,6,7-tetrabromo-1,3-dioxo-2,3-dihydro-1H-isoindol-2-yl) phenyl] phenyl\}-2,3-dihydro-1H-isoindole-1,3-dione (4):

Mud color solid; $\mathrm{mp}>300{ }^{\circ} \mathrm{C}$; yield $71 \%$; IR $\left(\mathrm{cm}^{-}\right.$ $\left.{ }^{1}\right): v_{\mathrm{C}=\mathrm{O}(\text { asym })} 1777, v_{\mathrm{C}=\mathrm{O}(\text { sym })} 1719, v_{\mathrm{CH}} 2985 ;{ }^{1} \mathrm{H}$ $\operatorname{NMR}\left(\left(\delta, \mathrm{ppm}\right.\right.$ in DMSO-d $\left.\mathrm{d}_{6}\right): 2.18\left(\mathrm{~s}, 6 \mathrm{H},-\mathrm{CH}_{3}\right)$; 7.84-7.87 (3H, Ar-H), 8.06-8.09 (3H, Ar-H). ${ }^{13} \mathrm{C}$ NMR $(100 \mathrm{MHz}$, DMSO-d 6 ) $\delta$ in ppm: 168.12, 167.26, 147.55, 136.87, 135.94, 131.36, 129.14, 126.97. 28.22. MS $(m / z) 1104.5(\mathrm{M}+1)$. Anal. Calcd. for $\mathrm{C}_{30} \mathrm{H}_{12} \mathrm{~N}_{2} \mathrm{O}_{4} \mathrm{Br}_{8}$ : C, 32.64; $\mathrm{H}, 1.09 ; \mathrm{N}, 2.53$; found: C, 32.66; H, $1.11 ; \mathrm{N}, 2.49$.

\section{DNA binding studies}

\section{Absorption measurements}

UV-visible spectroscopy is very suitable and significant method to evaluate the binding nature of small molecules and DNA. All the experiments were performed in tris- $\mathrm{HCl}$ buffer. The absorption ratio of Ct-DNA in buffer was 1.9:1 at $260 \mathrm{~nm}$ which reveals that DNA was possibly absolutely free from protein contamination (Raja et al. 2016). Absorption intensity was determined at $260 \mathrm{~nm}$ for the investigation of DNA concentration of stock solution using a molar absorption coefficient $\varepsilon_{260}=6600 \mathrm{~L} \mathrm{~mol}^{-1} \mathrm{~cm}^{-1}$ by UV-visible spectrophotometer (Kumar et al. 2016). Test samples were allowed to equilibrate at room temperature for $10 \mathrm{~min}$ before recording the absorption spectrum, carried out in the range of $190-500 \mathrm{~nm}$ by varying the concentration of the DNA $\left(1.2-3.0 \times 10^{-5} \mathrm{M}\right)$ and adapting the constant concentration of compound $\left(1 \times 10^{-4} \mathrm{M}\right)$.

\section{Viscosity measurements}

The viscosity was determined in the presence of increasing concentration of test compound $\left(0.4-2.0 \times 10^{-5} \mathrm{M}\right)$ and fixing the DNA concentration $\left(2.5 \times 10^{-5} \mathrm{M}\right)$ in the $5 \mathrm{mM}$ Tris-buffer $(\mathrm{pH}=7.2$ ). All the experiments were carried out using an Ostwald capillary viscometer maintained at $25 \pm 0.1^{\circ} \mathrm{C}$. The flow time of the test compounds through the viscometer was determined in triplicate to get the average and accurate value (Patel et al. 2014). The obtained data ploted as $\left(\eta / \eta_{\mathrm{o}}\right)^{1 / 3}$ versus [compound]/[DNA], where $\eta$ is the viscosity of Ct-DNA in the presence of compound and $\eta_{\mathrm{o}}$ is the viscosity of Ct-DNA alone. Relative viscosity of the test compound 1 was determined from the observed flow time of DNA solution $(t)$ corrected for the flow time of tris-buffer alone $\left(t^{0}\right)$, using the expression 1 .

$$
\eta_{\mathrm{o}}=\left(t-t^{0}\right) / t^{0}
$$

\section{Electrochemical study}

Cyclic voltammetry (CV) was performed to investigate the redox behavior of test compound 1 using DY2312 potentiostat. The electrochemical experiments were carried out with and without DNA in tris-buffer $(\mathrm{pH}=7.5)$. All the experiments were done at a scan rate $0.2 \mathrm{Vs}^{-1}$ in the potential range +1.2 to $-2.0 \mathrm{~V}$ at room temperature (Mazhabi and Arvand 2014). Experiment was performed in a electrochemical cell consisting three-electrode, platinum wire auxiliary electrode, glassy carbon working electrode, and silver/silver nitrate as a reference electrode. Alumina powder was used to polish the electrode surface, and for the deoxygenation of the test compounds, nitrogen gas had been used $20 \mathrm{~min}$ before the experiments.

\section{Antibacterial activity}

All the synthesized compounds were screened for antibacterial activity against gram-negative bacterium $E$. coli and gram-positive bacterium $S$. mutants using Kirby Bauer methods (1953) and broth dilution method (Boufas et al. 2014) which conformed to the recommended standards of the Clinical and Laboratory Standards Institute (CLSI). Ampicillin was used as a standard antibacterial drug. A diluted series with $10 \mathrm{~mL}$ nutrient broth medium containing $50-200 \mu \mathrm{g} / \mathrm{mL}$ of synthesized phthalimide derivatives were prepared. One hundred microliters of respective bacterial suspension (approximately $10^{6} \mathrm{CFU} / \mathrm{mL}$ ) was used to inoculate the each set. The bacteria were plated onto solid nutrient agar plates. MIC was defined as the lowest concentration for the inhibition of bacterial growth. All the experiments were done in triplicate and average was reported.

\section{Molecular docking study}

Phthalimide derivative 1 has been optimized using B3LYP method in conjunction with 6-31G** basis set utilizing Gaussian 03 (Yadava et al. 2015a, b). Absence of imaginary frequency modes for each molecule indicates that the true minima were achieved. Conformations of the molecule were generated and prepared through LIGPREP wizard of the SCHRODINGER suite (Yadava et al. 2013). The three-dimensional structure of the DNA duplex was retrieved from the protein data bank (PDB ID: 1BNA) which was prepared using protein preparation wizard. The electron affinity grid map was generated around the center of the DNA, and the docking of molecule was carried out using XP (extra precision) mode of GLIDE (Yadava et al. 2015a, b). During docking, ligand was treated as flexible while DNA was taken as rigid. Docking complex was considered for the calculation of glide energy and glide scores.

\section{Antioxidant activity}

\section{$D P P H$ free radical scavenging assay}

Antioxidant activity of all the phthalimide derivatives was evaluated against DPPH free radical according to the 
method reported by the Miliauskas et al. which was the best method based on electron transfer (Miliauskas et al. 2004). Test compound $(0.5-3.0 \mathrm{mg} / \mathrm{mL})$ and ascorbic acid $(0.2-1.4 \mathrm{mg} / \mathrm{mL})$ in DMSO was added to $0.1 \mathrm{mM} \mathrm{DPPH}$ $(3 \mathrm{~mL})$ in ethanol. All test compounds were incubated at $60{ }^{\circ} \mathrm{C}$ for $2 \mathrm{~h}$, and the decrease in absorbance was noted at $510 \mathrm{~nm}$ using UV-Vis spectrophotometer against a blank of ethanol and DMSO in 1:1. Absorbance of DPPH (control) solution was also recorded at same wavelength for comparative study. The $\mathrm{IC}_{50}$ in $(\mathrm{mg} / \mathrm{mL})$ was calculated from the graph between $\%$ antioxidant activity vs concentrations. For each of the tests, compound experiment was done in triplicate and antioxidant property of the compounds was measured by using Eq. 2:

$$
\% \text { Inhibition }=\frac{A_{\text {Control }}-A_{\text {Sample }}}{A_{\text {Control }}} \times 100
$$

where $A_{\text {control }}=$ absorbance of $\mathrm{DPPH}$ free radical in methanol without an antioxidant and $A_{\text {sample }}=$ absorbance of DPPH free radical in the presence of an antioxidant.

\section{Hydrogen peroxide scavenging activity}

The antioxidant ability of the phthalimide derivatives was also estimated by hydrogen peroxide using standard method (Ruch et al. 1989). To the different concentrations of test compounds, $1.8 \mathrm{~mL}$ of a $2 \mathrm{mM} \mathrm{H}_{2} \mathrm{O}_{2}$ solution prepared in phosphate buffer $(50 \mathrm{mM}, \mathrm{pH} 7.4)$ was added and the samples were incubated for $10 \mathrm{~min}$. We record the decrease in absorbance against phosphate buffer as a blank by UV-Vis spectrophotometer. The absorbance of test samples was noted at $240 \mathrm{~nm}$ and compared with hydrogen peroxide which was taken as a control. The antioxidant ability of hydrogen peroxide was calculated using following equation:

$$
\% \text { Inhibition }=\frac{A_{\mathrm{B}}-A_{\mathrm{T}}}{A_{\mathrm{B}}} \times 100
$$

where $A_{\mathrm{B}}$ was the absorbance of blank (without compounds) and $A_{\mathrm{T}}$ was the absorbance of tested samples.

\section{Results and discussion}

Phthalimide derivatives were prepared in good yield by the condensation reaction of tetrabromophthalic anhydride with substituted diamines of triazole, pyridine, and pyrimidine (Scheme 1). The structure of the compounds (1-4) was proposed on the basis of spectral data and elemental analysis. All the compounds are stable in solid state and soluble in DMSO and DMF. The progress of the reaction was monitored by thin layer chromatography (TLC) in methanol: dichloromethane (1:4).

\section{IR spectra}

IR spectra of synthesized phthalimide derivatives were recorded in the range $4000-400 \mathrm{~cm}^{-1}$. All the compounds were characterized by a vibrational band in the range of $1777-1793 \mathrm{~cm}^{-1}$. The stretching frequency due to $\mathrm{v}\left(-\mathrm{NH}_{2}\right.$ group) (3,5-diamino-1,2,4-triazole, 2,6-diaminopyridine and 2,4diamino-6-hydroxypyrimidine and o-tolidine) which disappear in the compounds (1-4) confirms the formation of bis-phthalimide derivatives. A characteristic peak appeared at $3454 \mathrm{~cm}^{-1}$ for the compounds (1) may be assigned due to the $v(-\mathrm{NH})$ group. However, a peak appeared at $3190 \mathrm{~cm}^{-1}$ for the compound (3) is assigned due to $\mathrm{v}(-\mathrm{OH})$ (Sas et al. 2015; Collin et al. 2001).

\section{${ }^{1} \mathrm{H}$ NMR spectra}

${ }^{1} \mathrm{H}$ NMR spectra of compounds were recorded in DMSO- $\mathrm{d}_{6}$ at room temperature exhibited well resolved signals depicted in Additional file 1: Figure S1. The signal due to $-\mathrm{NH}_{2}$ group in substituted amines disappear which indicate the formation bis-phthalimide derivatives (1-4). A singlet due to $-\mathrm{NH}$ group of triazole appear at $9.46 \mathrm{ppm}$ was assigned for the compound 1. Moreover, a singlet appeared at $9.54 \mathrm{ppm}$ attributed to the $-\mathrm{OH}$ for the compound (3). The signals due to aromatic protons in the compounds (1-4) appear at $6.52-8.13 \mathrm{ppm}$ (Pawluc et al. 2012; Antunes et al. 2003).

\section{DNA binding study Absorption measurements}

The binding ability of DNA with compound 1 was studied efficiently through absorption spectroscopy. The interaction ability of the compounds and DNA was investigated by the increase or decrease in the absorbance and shift in wavelength. Hypochromism or decrease in absorbance with red shifts in wavelength involved a strong stacking interaction between the DNA base pairs and aromatic chromophore although hyperchromism is associated with electrostatic or groove binding which also responsible for the damage of secondary structure of DNA. The absorption spectra of the compound 1 in presence and absence of DNA is given in Fig. 1. On increasing the concentration of DNA, absorbance decrease or hypochromism was observed which show that compound 1 bind with Ct-DNA by strong intercalative mode (Nayab et al. 2016).

Hypochromism was observed due to the stacking of the planar aromatic group of the compounds between adjacent base pairs of double helix DNA. Intrinsic binding constant $\left(K_{b}\right)$ was calculated by the Eq. 4: 

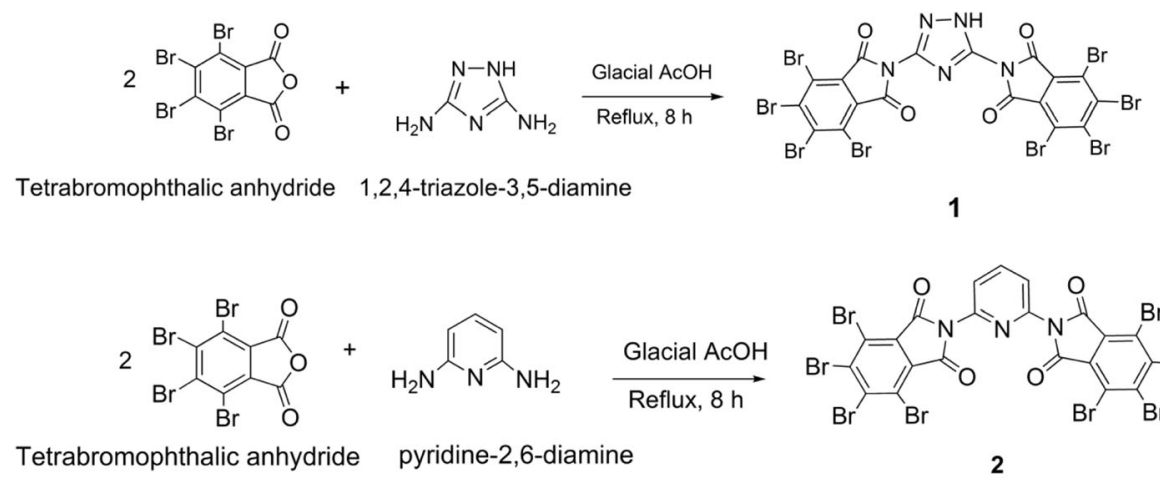

1

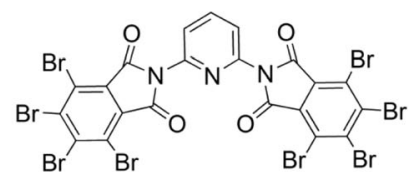

2

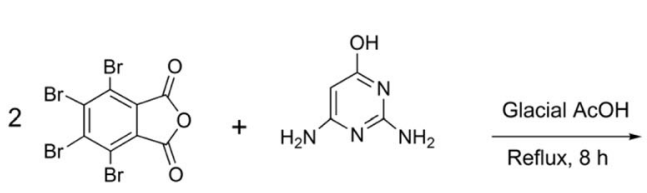

Tetrabromophthalic anhydride 2,6-diaminopyrimidin-4-ol

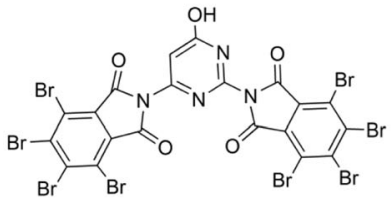

3
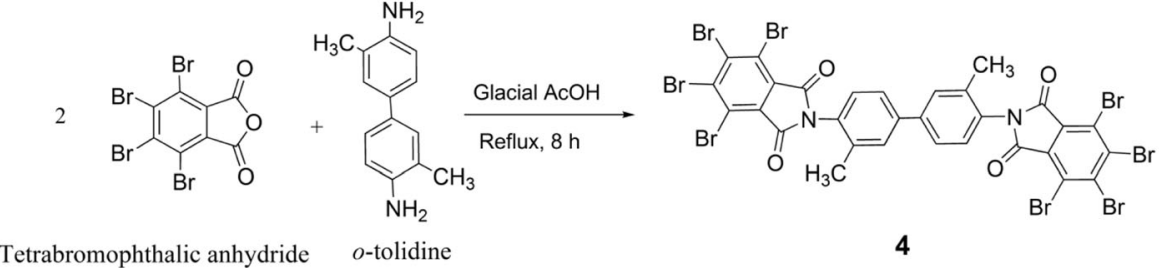

Tetrabromophthalic anhydride $o$-tolidine

Scheme 1 Synthesis of tetrabromo-bisphthalimide derivatives

$$
\frac{[\mathrm{DNA}]}{\left(\varepsilon_{a}-\varepsilon_{f}\right)}=\frac{[\mathrm{DNA}]}{\left(\varepsilon_{b}-\varepsilon_{f}\right)}+\frac{1}{K_{b}}\left(\varepsilon_{b}-\varepsilon_{f}\right)
$$

where $\varepsilon_{\mathrm{a}}, \varepsilon_{\mathrm{f}}$, and $\varepsilon_{\mathrm{b}}$ refers to $A_{\mathrm{obsd}} /[$ Compound], the absorption extinction coefficient for free compound and the absorption extinction coefficient for the compound in fully bound form, respectively. $K_{b}$ is slope to intercept ratio given by the plot, [DNA] $/\left(\varepsilon_{\mathrm{a}}-\varepsilon_{\mathrm{f}}\right)$ vs [DNA]. The DNA binding constant calculated for compound 1 was $4.7 \times 10^{6} \mathrm{M}^{-1}$.

\section{Viscosity measurements}

Viscometry measurement is a very significant tool for further estimation of binding nature of Ct-DNA with small molecule which is very critical and sensitive to length change. Classical intercalation leads to the adjustment of molecules between the base pairs of DNA which in turn increase the separation between base pairs at intercalation site and increases it helix length; therefore, viscosity increases. However, due to partial or non classical intercalation, led to bend or kink of DNA helix, results in reduction of the effective length of Ct-DNA and thereby decrease in viscosity (Arif et al. 2016). The effect of addition of increasing amount of test compound 1 on relative specific viscosity of DNA is shown in Fig. 2. On the addition of increasing amount of test compound 1 and fixing the Ct-DNA concentration, viscosity of Ct-DNA increases remarkably which notify that compound can intercalate between the base pairs of DNA and results are very similar with classical intercalators as corroborated by UV-Vis spectroscopic study.

\section{Electrochemical study}

Electrochemical method is another significant tool to clarify the mode of binding of compound with Ct-DNA. The positive shift in peak potential is due to the intercalation of the compound with Ct-DNA; however, negative shift is attributed to the electrostatic binding. The cyclic voltammograms of test compound 1 with and without DNA are shown in Fig. 3. It was inferred that after the addition of DNA, peak current was dropped by $19 \%$ for compound 1 . Decrease in current may be due to 


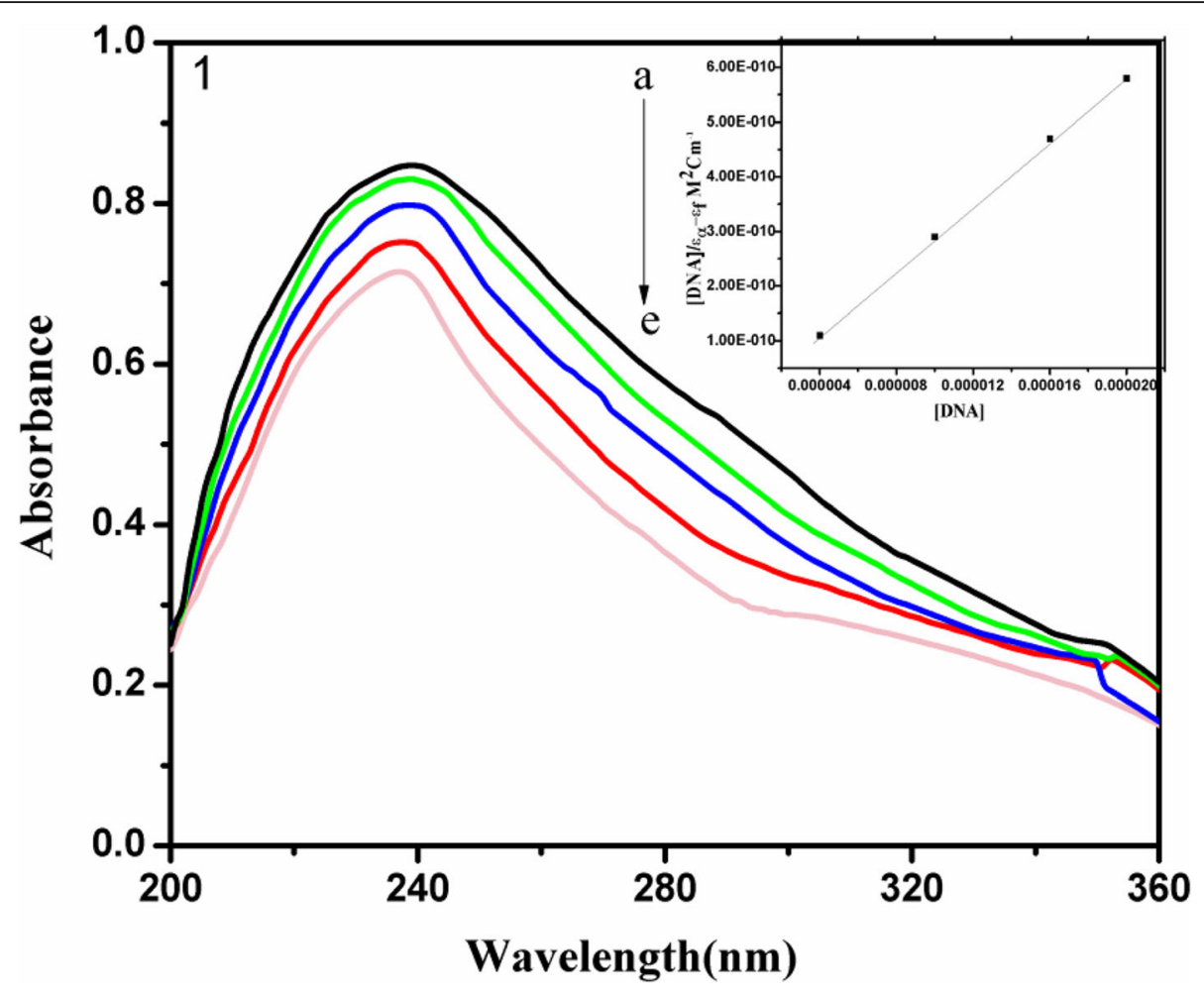

Fig. 1 Absorption spectra of compound $(1)\left(1 \times 10^{-4} \mathrm{M}\right)$ in the presence of increasing amounts of Ct-DNA $\left(1.2-3.0 \times 10^{-5} \mathrm{M}\right)$. The inset is plot of $[D N A] /\left(\varepsilon_{a}-\varepsilon_{f}\right)$ vs $[D N A]$ for the titration of DNA to compound

the formation of compound-DNA complex and decrease in free ligand concentration. These results are in accordance with viscosity measurements and absorption study.

\section{Antibacterial activity}

In vitro antimicrobial evaluation of synthesized phthalimide derivatives (1-4) was carried out against two

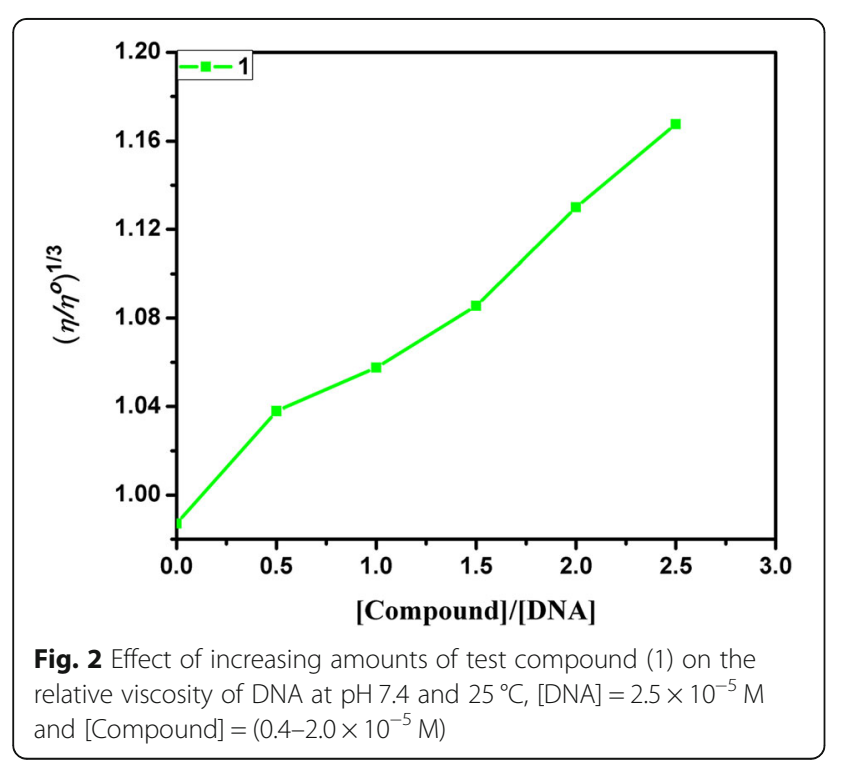

bacterial strains Escherichia coli (E. coli) and Streptococcus mutans (S. mutans) and ampicillin used as a positive control (Anacona et al. 2015). Results obtained revealed that out of all synthesized compounds, only compound 1 inhibited bacterial growths. MIC (minimal inhibitory concentration) was defined at lowest concentration that

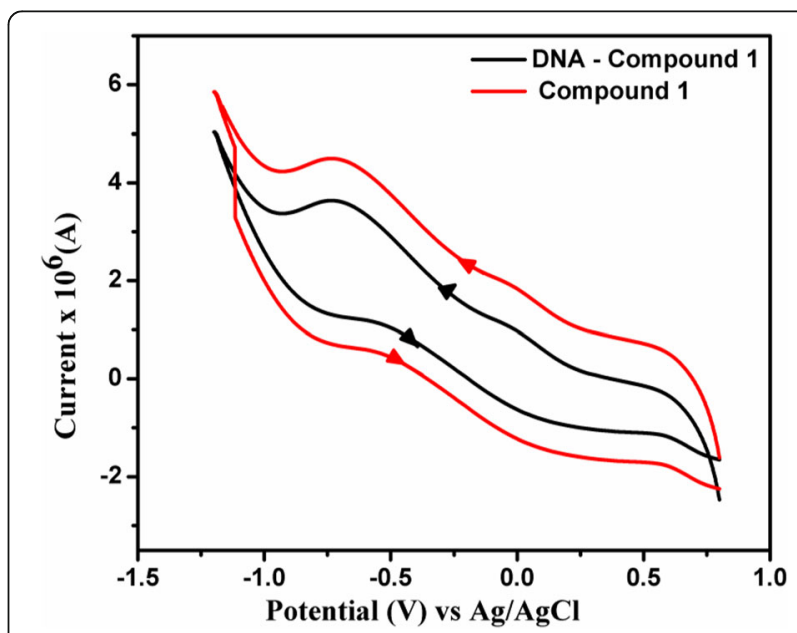

Fig. 3 Cyclic voltammograms of $3.2 \times 10^{-4} \mathrm{M}$ of test compound 1 in $1 \mathrm{mM}$ tris-buffer, $\mathrm{pH} 7.5$ at $50 \mathrm{mV} \mathrm{s}^{-1}$ scan rate without DNA (red) and with DNA (black) 
completely inhibited visible bacterial growth. The MBC values are $100 \mu \mathrm{g} / \mathrm{mL}$ and $150 \mu \mathrm{g} / \mathrm{mL}$ for compound 1 against E. coli and S. mutants, respectively, and compound 1 exhibits better activity than other compounds.

\section{Molecular docking study}

The results of extra precision glide docking of the molecules with the DNA duplex 5'(CGCGAATTCGCG)3' are presented in Fig. 4. Glide docking demonstrates that the best pose of compound 1 has the better glide score in comparison to other compounds. The glide scores in their best poses of compound 1 is $-5.772 \mathrm{kcal} / \mathrm{mol}$. The best docking pose of the compound 1 showed that the Emodel and glide energies equal to -59.905 and -45.704 $\mathrm{kcal} / \mathrm{mol}$ respectively. Figure 4 demonstrates that the compound 1 recognizes both strands of the DNA and binds within minor groove of the duplex. One hydrogen bonding has also been demonstrated by the compound 1 involving the thymine (DT7) base of the DNA.

Molecular docking results demonstrate that this compound recognizes both the strands of the DNA dodecamer $\mathrm{d}(\text { CGCGAATTCGCG })_{2}$ within minor groove. Docking results reveal that compound 1 has the best binding capability with the duplex. It may further be concluded that the binding of drug molecule with DNA is sequence dependent and the specific sequence of the DNA may be playing a key role in the binding process. These results may enhance future prospects for the drug development targeting DNA.

\section{Antioxidant activity}

\section{$D P P H$ free radical scavenging assay}

For the estimation of antioxidant activity of the test compounds, DPPH free radical assay is a very suitable and easy method. It is a stable free radical that can accept hydrogen ion or electron on reaction from an antioxidant compound and become reduced. After the incubation of $2 \mathrm{~h}$ at $60^{\circ} \mathrm{C}$, the color of the compounds changed from violet to light yellow which clearly reveals that some antioxidant moiety was present in compound. The decrease in the absorbance was noted at $510 \mathrm{~nm}$. The $\mathrm{IC}_{50}$ values of DPPH radical scavenging activity for the compounds $1,2,3$, and 4 were found to be $0.27 \pm 0.02, \quad 0.74 \pm 0.04, \quad 1.43 \pm 0.03$, and $0.97 \pm 0.02 \mathrm{mg} / \mathrm{mL}$ respectively (Additional file 1: Figure $\mathrm{S} 2$ ). Higher $\mathrm{IC}_{50}$ value refers to weaker capacity of compounds to scavenge DPPH free radical. The results obtained from antioxidant assay reveals that compound 1 shows better scavenging activity.

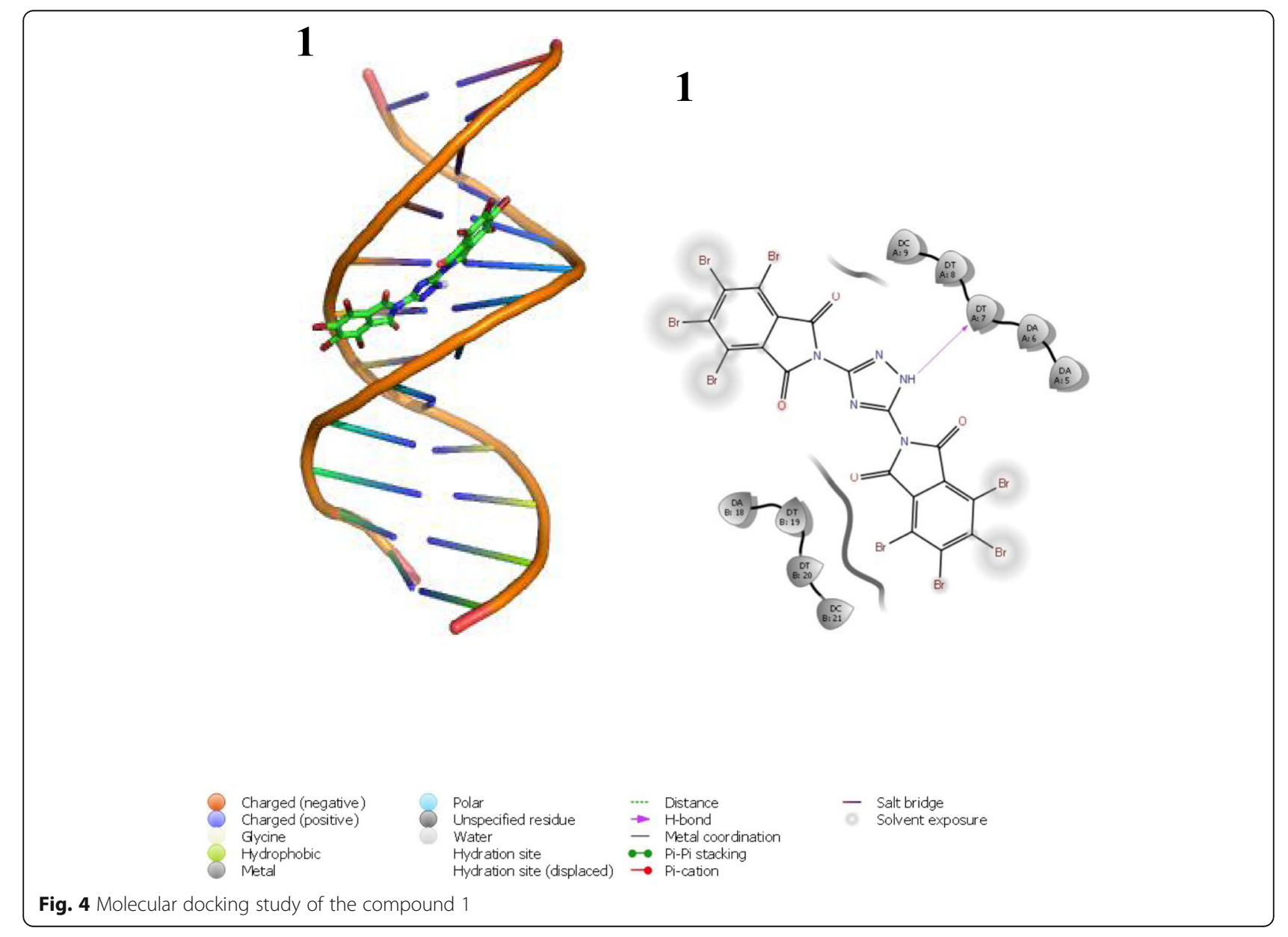




\section{Hydrogen peroxide scavenging activity}

Hydrogen peroxide is another very reactive species among all the oxygen-containing compound. Therefore, the antioxidant potential of test compounds was also estimated by hydrogen peroxide scavenging assay. The capabilities of target compounds to scavenge the hydrogen peroxide radicals were monitored using UV-Vis spectrophotometer. The $\mathrm{IC}_{50}$ values of scavenging activity for the compounds $1,2,3$, and 4 were found to be $0.41 \pm 0.014,0.79 \pm 0.015,1.30 \pm 0.028$, and 1.23 $\pm 0.021 \mathrm{mg} / \mathrm{mL}$ respectively (Additional file 1: Figure S3). The investigation of antioxidant assay demonstrates that compound 1 showed the greater rate of $\mathrm{H}_{2} \mathrm{O}_{2}$ scavenging activity than other compounds and the results are in accordance with the results obtained by DPPH free radical method.

As compared to our previous study (Arif et al. 2016), it has been found that the derivatives of tetrabromophthalimide could interact to calf thymus DNA via strong intercalative mode of binding. It also conluded that tetrabromo-phthalimide derivatives bind more strongly to Ct-DNA as compared to phthalimide and tetrachloro-phthalimide derivatives followed by absorption measurements. Antioxidant study demonstrates that compounds (1-4) showed better antioxidant activity against DPPH free radical and hydrogen peroxide.

\section{Conclusions}

In this work, we have synthesized a series of $\mathrm{N}$-substituted tetrabromophthalimide derivatives (1-4) and characterized structurally by elemental analysis, FT-IR, and ${ }^{1} \mathrm{H}$ NMR spectral analysis. Synthesized compounds were evaluated for their antibacterial potential against $E$. coli and $S$. mutans, and it has been found that better results were found in the case of compound 1. On the basis of antibacterial potency, binding interactions of compound 1 with DNA were investigated by using absorbance, hydrodynamics, and cyclic voltammetry measurement methods against Ct-DNA. Compound 1 showed strong intercalation with Ct-DNA, and it was concluded that compound 1 could interact with DNA via classical intercalative mode. Antioxidant assays demonstrated that the test compounds showed good scavenging activity against DPPH free radical and $\mathrm{H}_{2} \mathrm{O}_{2}$.

\section{Additional file}

Additional file 1: Figure S1. ${ }^{1} \mathrm{H}$ and ${ }^{13} \mathrm{C}$ NMR spectra of the

compound 1. Figures S2. and $\mathbf{S 3}$. Graphs for the antioxidant assay of the compounds 1,2,3 and 4 against DPPH free radical and hydrogen peroxide are given. (DOC $4623 \mathrm{~kb}$ )

\section{Acknowledgements}

The financial support from University Grants Commission, Govt. of India for Major Research Project, is gratefully acknowledged. Mr. Rizwan Arif grateful to UGC, New Delhi for the financial support through Non-NET fellowship.

\section{Funding}

University Grants Commission (F.No. 41-238/2012).
Availability of data and materials

Data sharing not applicable to this article as no datasets were generated or analysed during the current study.

\section{Authors' contributions}

RA and PSN synthesized the phthalimide derivatives and investigate DNA binding interactions. RU and AA interpreted the data. MA and UY conducted the docking experiments. All authors read and approved the final manuscript.

\section{Competing interests}

The authors declare that they have no competing interests.

\section{Publisher's Note}

Springer Nature remains neutral with regard to jurisdictional claims in published maps and institutional affiliations.

\section{Author details}

1Department of Chemistry, Jamia Millia Islamia, New Delhi 110025, India. ${ }^{2}$ Department of Biosciences, Jamia Millia Islamia, New Delhi 110025, India. ${ }^{3}$ Department of Physics, DDU Gorakhpur University, Gorakhpur 273009, India.

Received: 8 September 2018 Accepted: 1 April 2019

Published online: 23 April 2019

\section{References}

Al-Qaisi JA, Alhussainy TM, Qinna NA, Matalka KZ, Al-Kaissi EN, Muhi-Eldeen ZA. Synthesis and pharmacological evaluation of aminoacetylenic isoindoline-1,3dione derivatives as anti-inflammatory agents. Arab J Chem. 2014;7:1024-30.

Anacona JR, Noriega N, Camus J. Synthesis, characterization and antibacterial activity of a tridentate Schiff base derived from cephalothin and sulfadiazine, and its transition metal complexes. Spectrochim Acta A. 2015;137:16-22.

Antunes R, Batista H, Srivastava RM, Thomas G, Araujo CC, Longo RL, Magalhaes $H$, Leao MBC, Pavao AC. Synthesis, characterization and interaction mechanism of new oxadiazolo-phthalimides as peripheral analgesics. IV. J Mol Str. 2003;660:1-13.

Arif R, Nayab PS, Rahisuddin. Synthesis, characterization, DNA binding, antibacterial and antioxidant activity of new bis-phthalimides. Russian J Gen Chem. 2016:86:1374-80.

Balachandran V, Lalitha S, Rajeswari S. Density functional theory, comparative vibrational spectroscopic studies, NBO, HOMO-LUMO analyses and thermodynamic functions of $\mathrm{N}$-(bromomethyl) phthalimide and $\mathrm{N}$ (chloromethyl) phthalimide. Spectrochim Acta A. 2012;91:146-57.

Behniafar H, Akhlaghinia B, Habibian S. Synthesis and characterization of new soluble and thermally stable poly (ester-imide)s derived from N-[3,5-bis(N-trimellitoyl) phenyl] phthalimide and various bisphenols. Eur Pol J. 2015:41:1071-8.

Bhat MA, Al-Omar MA. Synthesis, characterization and in vivo anticonvulsant and neurotoxicity screening of schiff bases of phthalimide. Acta Pol Pharm. 2011;68:375-80.

Boufas W, Dupont N, Berredjem M, Berrezag K, Becheker I, Berredjem H, Aouf N Synthesis and antibacterial activity of sulfonamides. SAR and DFT studies. J Mol Str. 2014;1074:180-5.

Buddana SK, Varanasi YVN, Shetty PR. Fibrinolytic, anti-inflammatory and antimicrobial properties of a-(1-3)-glucans produced from Streptococcus mutans (MTCC 497). Carbohydr Polym. 2015;115:152-9.

Cho DW, Quan C, Park HJ, Choi JH, Kim SR, Hyung TG, Yoon UC, Kim SH, Jin YX, Mariano PS. Studies aimed at elucidating factors involved in the control of chemoselectivity in single electron transfer promoted photoreactions of branched-poly donor substituted phthalimides. Tetrahedron. 2010;66:3173-86.

Choi JH, Lee HY, Towns AD. Dyeing properties of novel azo disperse dyes derived from phthalimide and color fastness on poly(lactic acid) fiber. Fiber Polym. 2010;11:199-204.

Collin X, Robert J, Wielgosz G, Baut GL, Bobin-Dubigeon C, Grimaud N, Petit J. New anti-inflammatory N-pyridinyl (alkyl) phthalimides acting as tumour necrosis factor-a production inhibitors. Eur J Med Chem. 2001;36:639-49.

Krishnakumar V, Balachandran V, Chithambarathanu T. Density functional theory study of the FT-IR spectra of phthalimide and N-bromophthalimide. Spectrochim Acta A. 2005;62:918-25

Kumar GS, Ali MA, Choon TS, Prasad KJR. Synthesis, DNA binding and cytotoxic evaluation of aminoquinoline scaffolds. J Chem Sci. 2016;128:391-400. 
Kushwaha N, Kaushik D. Recent advances and future prospects of phthalimide derivatives. J App Pharma Sci. 2016;6:159-71.

Li Y, Li C, Du C, Cong Y, Cheng C, Zhao H. Solubility determination and modelling for phthalimide in mixed solvents of (acetone, ethyl acetate or acetonitrile + methanol) from (278.15 to 313.15) K. J Chem Thermodynamics. 2017; 106:123-31

Lin P, Hsieh Y, Tsai C. Antagonistic activity of Lactobacillus acidophilus RY2 isolated from healthy infancy feces on the growth and adhesion characteristics of enteroaggregative Escherichia coli. Anaerobe. 2009;15:122-6.

Lohan S, Monga J, Cameotra SS, Bisht GS. In vitro and in vivo antibacterial evaluation and mechanistic study of ornithine based small cationic lipopeptides against antibiotic resistant clinical isolates. Eur J Med Chem. 2014;88:19-27.

Mazhabi RM, Arvand M. Disposable electrochemical DNA biosensor for environmental monitoring of toxicant 2-aminoanthracene in the presence of chlorine in real samples. J Chem Sci. 2014;126:1031-7.

Miliauskas G, Venskutonis PR, Beek TAV. Screening of radical scavenging activity of some medicinal and aromatic plant extracts. Food Chem. 2004;85:231-7.

Mohamed TA, Shaaban IA, Farag RS., Zoghaib WM, Afifi MS. Synthesis, antimicrobial activity, structural and spectral characterization and DFT calculations of $\mathrm{Co}(\mathrm{II}), \mathrm{Ni}(\mathrm{II}), \mathrm{Cu}(\mathrm{II})$ and $\mathrm{Pd}(\mathrm{II})$ complexes of 4-amino-5pyrimidinecarbonitrile. Spectrochim Acta A 2015; 135: 417-427.

Nayab PS, Arif R, Arshad M, Rahisuddin. Synthesis, characterization, antibacterial, DNA binding and molecular docking studies of novel N-substituted phthalimides. Heterocyclic Lett. 2016;5:223-9.

Nayab PS, Pulaganti M, Chitta SK, Rahisuddin. Multi-spectroscopic and molecular docking studies on the interaction of new phthalimides with calf-thymus DNA: In vitro free radical scavenging activities. Spectrosc Lett. 2016;49:108-17.

Nayab PS, Pulaganti M, Chitta SK, Rahisuddin. A new isoindoline based Schiff base derivative as $\mathrm{cu}(\mathrm{II})$ chemosensor: synthesis, photophysical, DNA binding and molecular docking studies. J Fluoresc. 2015b;25:1763-73.

Nayab PS, Pulaganti M, Chitta SK, Abid M, Rahisuddin. Evaluation of DNA binding, radicals scavenging and antimicrobial studies of newly synthesized $\mathrm{N}$ substituted naphthalimides: spectroscopic and molecular docking investigations. J Fluoresc. 2015a;25:1905-20.

Patel M, Joshi HN, Patel CR. Cytotoxic, DNA binding, DNA cleavage and antibacterial studies of ruthenium-fluoroquinolone complexes. J Chem Sci. 2014;126:739-49.

Pawluc P, Franczyk A, Walkowiak J, Hreczycho G, Kubicki M, Marciniec B. Highly stereoselective synthesis of $\mathrm{N}$-substituted $\mathrm{p}$-conjugated phthalimides. Tetrahedron. 2012;68:3545-51.

Raja K, Suseelamma A, Reddy KH. Synthesis, X-ray crystal structure, DNA binding and nuclease activity of lanthanide(III) complexes of 2-benzoylpyridine acetylhydrazone. J Chem Sci. 2016;128:1265-75.

Roy J, Breton B, Martel C, Labrie F, Poirier D. Chemical synthesis and biological activities of $16 a$-derivatives of $5 a$-androstane-3a,17 $\beta$-diol as antiandrogens. Bioorg Med Chem. 2007;15:3003-18.

Ruch RJ, Cheng SJ, Klaininig JE. Prevention of cytotoxicity and inhibition of intercellular communication by antioxidant catechins isolated from Chinese green tea. Carcinogen. 1989;10:1003-8.

Sang Z, Wang K, Wang H, Yu L, Wang H, Ma Q, Mengyao Y, Han X, Liu W. Design, synthesis and biological evaluation of phthalimide-alkylamine derivatives as balanced multifunctional cholinesterase and monoamine oxidase-binhibitors for the treatment of Alzheimer's disease. Bioorg Med Chem Lett. 2017;22:5053-9.

Sas EB, Kose E, Kurt M, Karabaca M. FT-IR, FT-Raman, NMR and UV-vis spectra and DFT calculations of 5-bromo-2-ethoxyphenylboronic acid (monomer and dimer structures). Spectrochim Acta A. 2015;137:1315-33.

Shi JB, Xu S, Wang YP, Li JJ, Yao QZ. Synthesis of new pyrimidine nucleoside derivativeswith nitric oxide donors for antiviral activity. Chinese Chem Lett. 2011;22:899-902.

Silva SDC, Souza MGM, Cardoso MJO, Moraes TS, Ambrosio SR, Veneziani RCS, Martins CHG. Antibacterial activity of Pinus elliottii against anaerobic bacteria present in primary endodontic infections. Anaerobe. 2014;30:146-52.

Wang S, Wang J, Gong P, Gao JG, Liu RZ, Wang YE, Xin XQ, Wang JH. Food Re Dev. 2013;82:1.

Yadava U, Gupta H, Roychoudhury M. Stabilization of microtubules by taxane diterpenoids: insight from docking and MD simulations. J Biol Phys. 2015a;41:117-33.

Yadava U, Shukla BK, Roychoudhury M, Kumar D. Pyrazolo [3,4-D] pyrimidines as novel inhibitors of O-acetyl-L-serine sulfhydrylase of Entamoeba histolytica: an in silico study. J Mol Model. 2015b;21:96-108.
Yadava U, Singh M, Roychoudhury M. Pyrazolo[3,4-d] pyrimidines as inhibitor of anti-coagulation and inflammation activities of phospholipase $A_{2}$ : insight from molecular docking studies. J Biol Phys. 2013;39:419-38.

Yoon UC, Kim JW, Ryu JY, Cho SJ, Oh SW, Mariano PS. Single electron transfer induced photocyclization reactions of $\mathrm{N}$-[(N-trimethylsilylmethyl) aminoalkyl] phthalimides. J Photochem Photobio A. 1997;106:145-54.

Zhang J, Movahedi A, Wang X, Wu X, Yin T, Zhuge Q. Molecular structure, chemical synthesis, and antibacterial activity of ABP-dHC-cecropin a from drury (Hyphantria cunea). Peptides. 2015;68:197-204.

\section{Submit your manuscript to a SpringerOpen ${ }^{\circ}$ journal and benefit from:}

- Convenient online submission

- Rigorous peer review

- Open access: articles freely available online

- High visibility within the field

- Retaining the copyright to your article

Submit your next manuscript at $\boldsymbol{\nabla}$ springeropen.com 